PIOTR ZWOLAN

Polish Naval Academy, Gdynia, Poland

KRZYSZTOF CZAPLEWSKI

Gdynia Maritime University, Poland

\title{
METHODOLOGY OF CREATION THE SIMULATION BASIN BASED ON THE PROJECTED CANAL THROUGH THE VISTULA SPIT
}

\begin{abstract}
The biggest problem in the process of implementation of the new sea areas project or aids to navigation systems is to check the assumptions without compromising security on real waters. Today, digital models are available for easy and inexpensive replacement of the research methods used so far. For this purpose the navigational and maneuvering simulators are perfect.

Simulators as a research tools allow you to define a more realistic and accurate data for the study and evaluation sea areas. The purpose of the simulation is to identify and reduce the risk for seafarers during navigation on the waterways, canals and port areas. These include quantitative and qualitative assessment of the canals and fairways construction. The main requirement for a simulation system is to have a multi-task simulation software, which includes effective tools for repositioning and designing safe waterways and port infrastructure.

The Institute of Navigation and Maritime Hydrography of the Polish Naval Academy since the eighties of the twentieth century is carried out projects in the field of navigational and hydrographic support of human activities at sea. This is possible thanks to the extensive set of simulation tools. Planning this tasks in a simulators software environment allow not only to design of virtual counterparts of real sea areas, but also to evaluate the quality of manufactured parts before their actual exposure to sea areas.
\end{abstract}

\section{Keywords:}

maritime simulation, simulators, design the simulated basin. 


\section{INTRODUCTION}

Due to the current political situation, access to the Vistula Lagoon is limited as it is either periodically closed or European Union vessels are not allowed to enter its waters from the Baltic Sea through the Pilava Strait. This situation compels the Polish government to work on delineating a new, alternative international waterway that would connect the Baltic Sea with the port of Elblagg and smaller ports that are located on the Vistula Lagoon. The project is primarily of economic significance since the creation of a navigable canal that would go through the Vistula Spit is a prerequisite for a more effective exploitation of the potential of the port of Elblacg, which was modernised in 2003, and for a significant increase in the lagoon's importance to tourist and recreational sailing. Four alternative locations where a cut could be made through the spit were suggested, i.e. near the following localities: Skowronki, Nowy Świat, Przebrno and Piaski. Then three different designs of the cut were proposed; these variants mainly differ in terms of the arrangement of wharves and the location of the entrance to the cut. This paper shows how the navigational limitations of the cut that is planned be made through the Vistula Spit can be assessed by using a navigation and manoeuvring simulator. The study was conducted based on analysing the behaviour of a vessel with the maximum dimensions for manoeuvring in the canal with the aim of identifying the best design variant. A navigation and manoeuvring simulator produced by Transas Marine, which is used by the Polish Naval Academy, served as a research tool. A wide range of vessel models, with different manoeuvring characteristics, are available in this simulator. The Navi-Trainer 5000 software, based on which the simulator operates, also includes the Model Wizard, a technologically advanced application which makes it possible to create new bodies of water for training and edit the existing ones [Navi-Trainer, 2011]. By using this application, a training water body that encompassed a cut through the Vistula Spit was created in accordance with the data that had been obtained from the Maritime Office in Gdynia. Then, manoeuvring tests were conducted in different hydro-meteorological conditions for the three variants of the entrance to the cut. Due to the diverse skills and experience of the research team's members, the simulation experiments were reliable and demonstrated any navigational dangers associated with the cut. 


\section{GENERAL CHARACTERISTICS OF THE DESIGN OF THE CUT THROUGH THE VISTULA SPIT}

There are four alternative locations of the navigable canal that is planned to be constructed through the Vistula Spit, from which the one that will be the best in economic and environmental terms will be chosen.

Experts decided that the best locations for the project will be the following:

- ALTERNATIVE 1 - Skowronki in the Sztutowo Commune;

- ALTERNATIVE 2 - Nowy Świat in the Sztutowo Commune;

- ALTERNATIVE 3 - Przebrno in the Krynica Morska Commune;

- ALTERNATIVE 4 - Piaski in the Krynica Morska Commune.



Fig. 1. Proposed locations for making a cut through the spit

Regardless of which of the alternatives will be selected, the newly built body of water will be equipped, for example, with a canal lock, storm gates, a berth, two drawbridges or a permanent bridge (about $17 \mathrm{~m}$ high) or a tunnel (13 m deep), and other facilities, with the following approximate parameters:

- a length, depending on the location, of: $1150 \mathrm{~m}$ — 'Skowronki', $1260 \mathrm{~m}$ 'Nowy Świat', $1650 \mathrm{~m}$ — 'Przebrno' and $750 \mathrm{~m}$ — 'Piaski'; 
- a basic width of $60 \mathrm{~m}$, which will be increased to $100 \mathrm{~m}$ at a distance of $200 \mathrm{~m}$ from the beginning of the canal;

- a depth of about $5 \mathrm{~m}$;

- a cubic volume of the cut, depending on the location, of: 1.26 million $\mathrm{m}^{3}-$ 'Skowronki', 1.74 million $\mathrm{m}^{3}$ - 'Nowy Świat', 1.96 million $\mathrm{m}^{3}-$ 'Przebrno' and 0.79 million $\mathrm{m}^{3}$ — 'Piaski';

- a canal lock with the following dimensions: a length of about $200 \mathrm{~m}$, a width of about $25 \mathrm{~m}$ and a depth of about $5 \mathrm{~m}$.

A general design concept of the canal was adopted based on the 'Skowronki' alternative, which is presented in Figure 2. It includes two alternative entrances, i.e. on the west and east sides of the canal. In the variant that features two drawbridges, which are located above the lock heads, one of the bridges would always be passable [2].

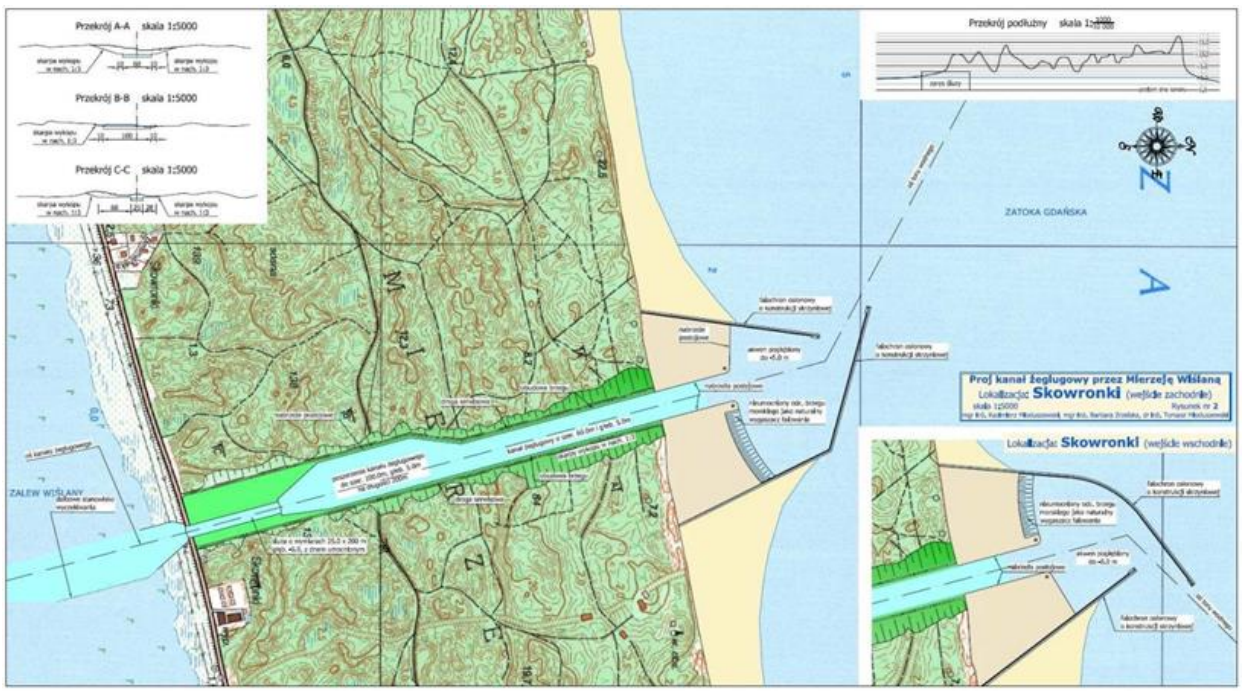

Fig. 2. Design concept of a navigable canal through the Vistula Spit alternative 1 'Skowronki' [source: www.umgdy.gov.pl/]

The following maximum dimensions of vessels that could safely manoeuvre in the cut were adopted:

- a length of up to $100 \mathrm{~m}$;

- a width of up to $20 \mathrm{~m}$;

- a draught of up to $4 \mathrm{~m}$. 


\section{PROCESS OF CREATING A BODY OF WATER IN A SIMULATED ENVIRONMENT}

The process of creating a water body in the environment of the Navi-Trainer Pro 5000 simulator, which involves using the specialist software Model Wizard [3], is complex and time-consuming. This process requires preparing a large amount of essential data and knowing how to use specialist software. The time that is needed for this depends on the accessibility of information sources, the shoreline's complexity and the number of additional objects that are necessary for creating a given body of water. This process occurred in accordance with the algorithm below.

\section{Selecting an S-57 ENC cell or raster chart showing a particular area}

In order to generate a water body with a high degree of detail and position it in space as accurately as possible, one must use official charts. An S-57 ENC p14map41 cell, which had been created by the Navy Hydrographic Office, was used as a basis for developing a body of water representing a cut through the Vistula Spit. Satellite images that have been superimposed on a chart can be used to verify the correctness of the simulated shoreline and compare it against the actual shoreline. Having selected the appropriate chart cell, one has to import it into the program. When an S-57 cell has been implemented, it becomes transformed into the TX97 format, which is used by the Model Wizard software. While changing formats, the program automatically imports the existing shoreline together with the navigation marks, bathymetric characteristics and heights.

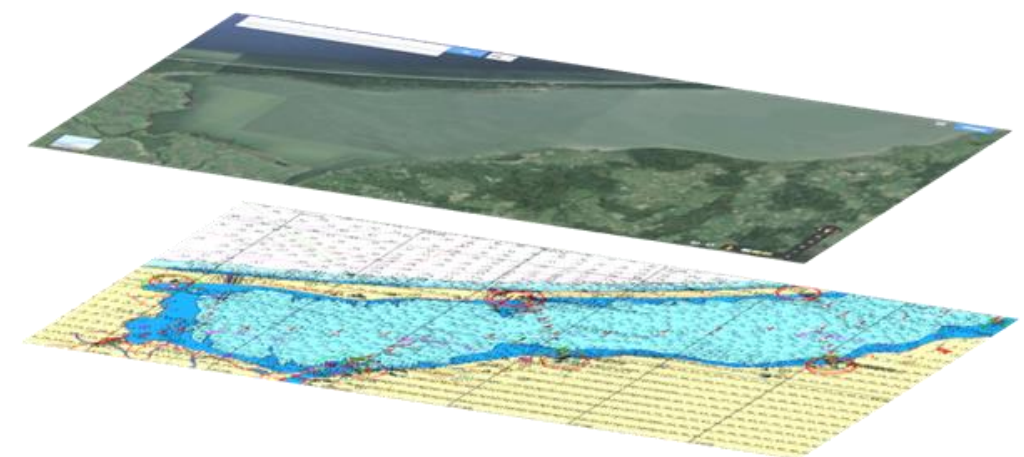

Fig. 3. ENC pl4map41 cell converted into the TX97 format and a satellite image 


\section{Editing the existing shoreline and creating a new one}

After the basic shoreline has been generated, the editing process begins. During the transformation of the shoreline, parameters such as altitude, type of shoreline (e.g. a shoreline designed for mooring) and construction material used on the shoreline (e.g. sand and stones) are edited.

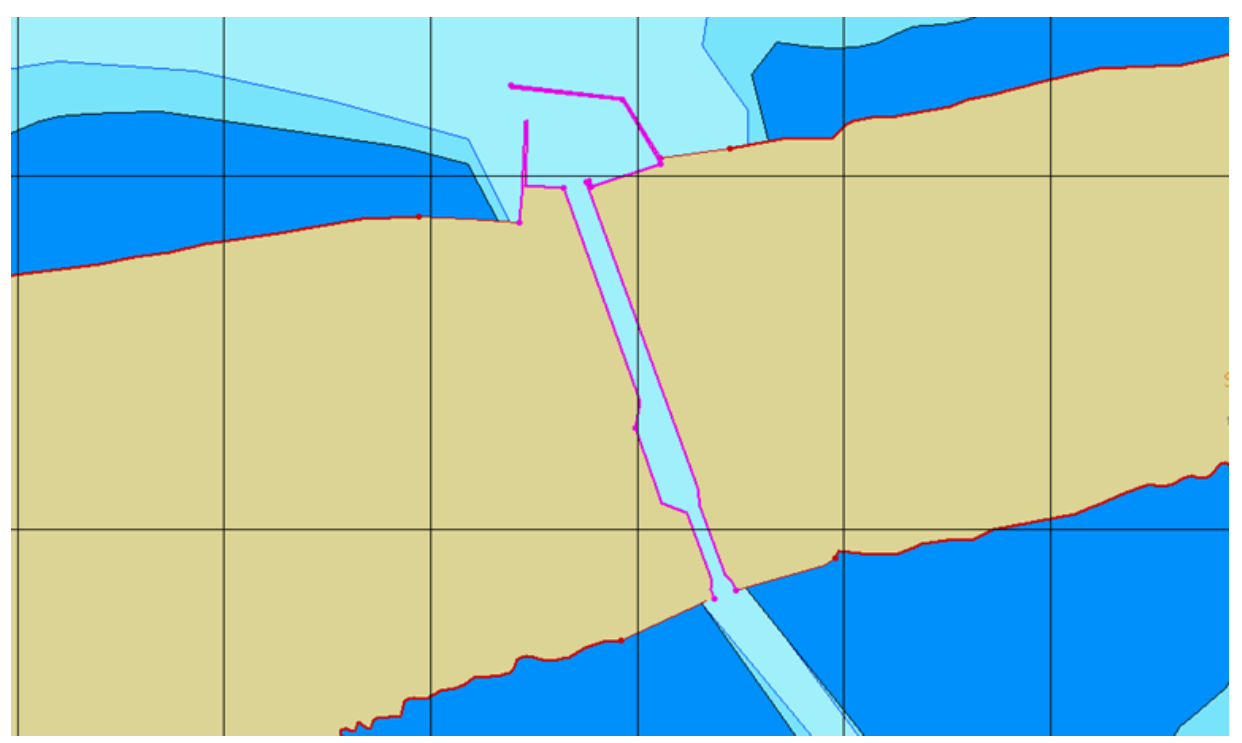

Fig. 4. Editing the generated shoreline

Apart from correcting the existing shoreline, it is also possible to create a new one based on construction plans in the form of a raster chart or any kind of bitmap in order to precisely draw a given area. Bitmaps and the dimensions that had been used in a feasibility study were employed to create three variants of a virtual model of the entrance to the cut. Accurate mapping of the shoreline will allow one to later generate a cell of an electronic navigational chart which will show the specific area.

\section{Editing bathymetric information}

Since it is possible that the depth data that are shown on the charts might not be up-to-date, it may be necessary to correct them. In order to do this, one 
must change the shape of the isobaths or add new ones. One can also map particular depth points and altitudes onto the chart. When working on the cut's model, it was necessary to create a new depth grid for the selected area. After all the essential corrections to the bathymetric data have been made, one should verify their accuracy. The Model Wizard program has a function that allows one to generate a preview of a given area's topography (the Sensor Viewer function). When analysing a 3D visualisation that was generated by the Sensor Viewer, one can notice random individual points representing wrong depth values. The figure below shows a three-dimensional model of the bottom of the cut.

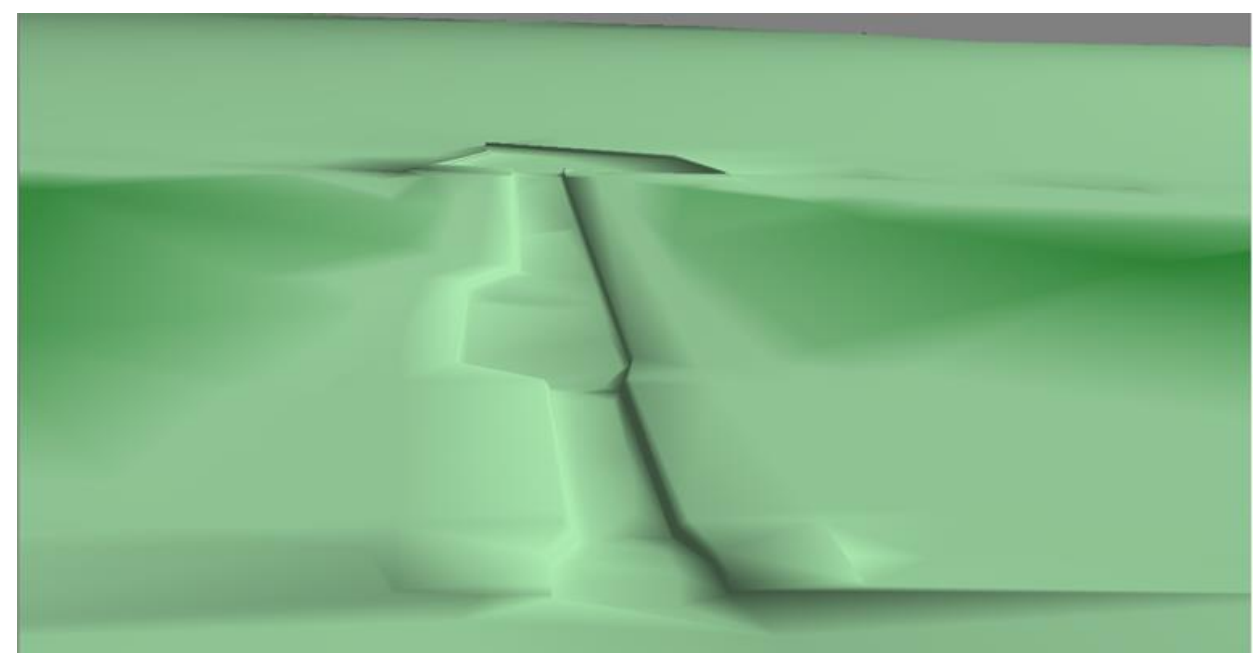

Fig. 5. Image generated by the Sensor Viewer

\section{Editing the terrain layer}

The area of the Vistula Spit that is located in close proximity to the cut does not have very diverse surface features as it is mostly covered by trees, grass and sand. One can use a library of objects that are included in the program to generate a land cover grid. The flat layers that are adjacent to the canal and the entrance to the port are created by superimposing the appropriate layers which are located at different heights above the water surface. These layers were covered by materials with various structures. 


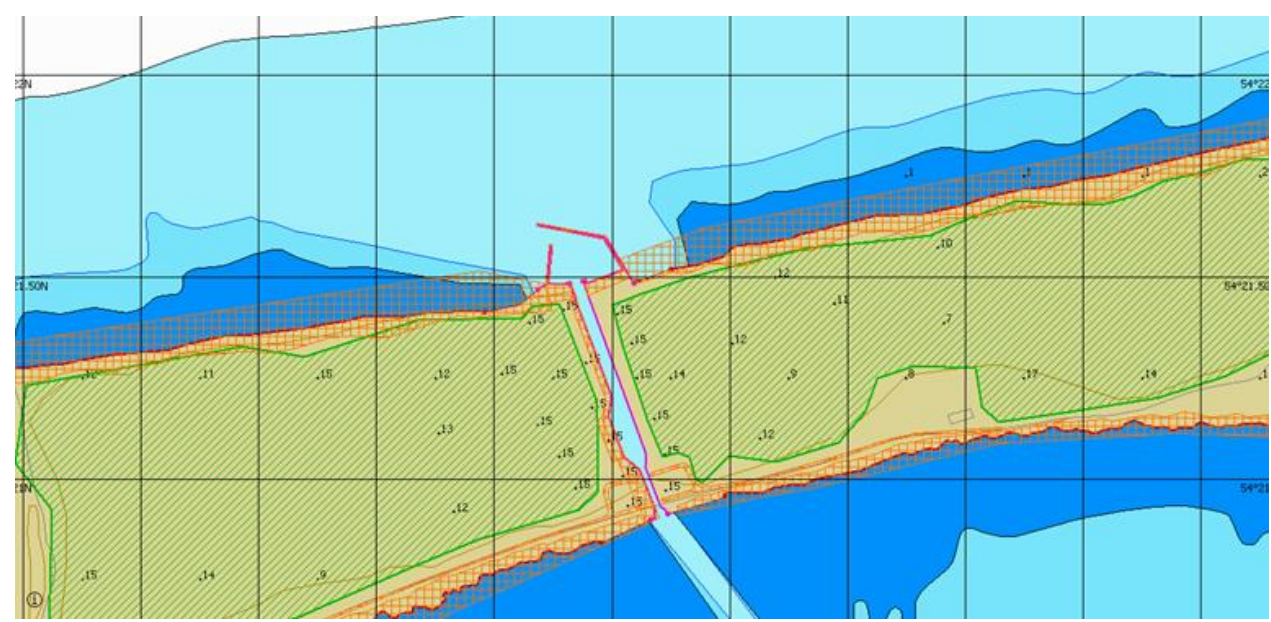

Fig. 6. Editing the generated topography

\section{Creating a navigational infrastructure with navigation marks}

After generating the topography and accurately mapping the shoreline together with the port basin and navigable canal, one can begin the process of creating the navigational infrastructure. Certain navigation marks and elements of port infrastructure that are included in the program's library of objects were used to create the body of water representing the cut through the Vistula Spit, along with newly generated objects. A canal lock is an example of the latter. In order to generate a lock, one must additionally use a program for creating 3D objects. It is essential that an object that has been created have the .3do extension since only files with this extension can be imported to the Model Wizard. Among these programs are AutoCad, 3D Studio Max and the extended version of Google SketchUp. The process of designing and creating 3D objects can be divided into four basic stages, which are presented below.

\section{STAGE 1 - collecting data about the objects that are being created}

This is the preliminary stage of generating 3D objects, which involves developing a database of photographic data and completing all the necessary information about the structures of the objects that are being created. Each of the 
elements is very important because when properly made, photographs that are to serve as textures allow one to realistically represent an object in a simulated environment. However, it is the data on the actual dimensions of particular elements of the navigational infrastructure and on their spatial location that are the most important. It was necessary to develop a model of the canal lock and the bridges, which were not available in the program's database of objects, in order to create a virtual model of the cut.

\section{$S T A G E 2$ - creating a the structure of an object}

After collecting all the data that are necessary to generate the elements of the navigational infrastructure, one can proceed to the next stage, which involves creating a grid. Previously prepared textures will later be placed on this grid. The figure below shows an example of the canal lock's structure.

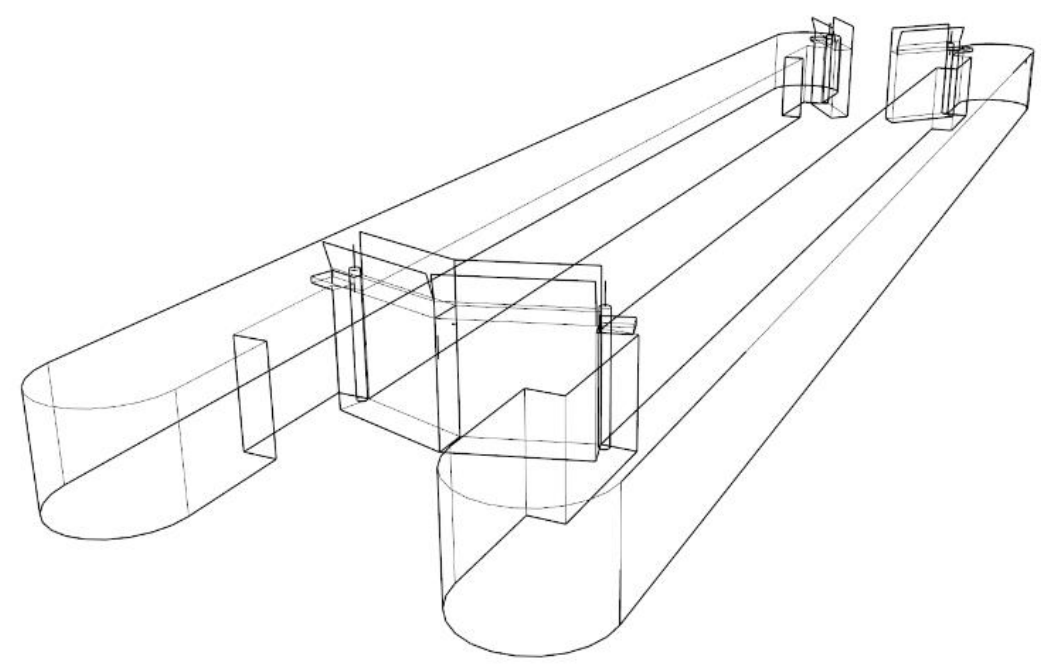

Fig. 7. Structure of the lock

STAGE 3 - connecting the points (closing the shape) and filling the area

The third stage involves connecting all of the loose lines and points of the grid and verifying the connectivity between all the planes that form a closed solid. 


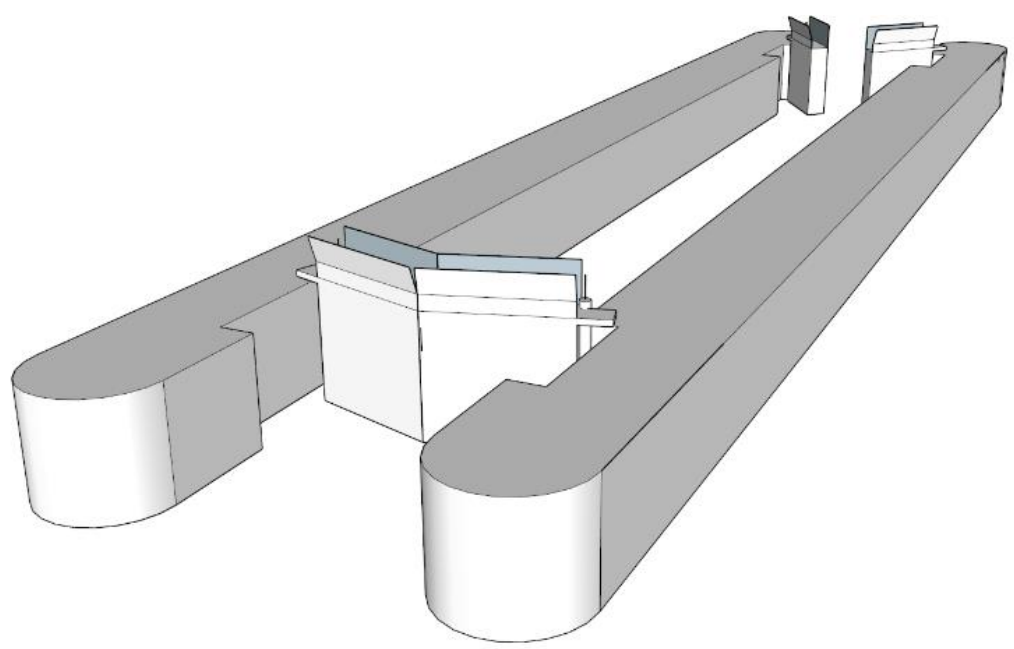

Fig. 8. Filling the area of an object

STAGE 4 - superimposing a texture on the object that has been created

At the last stage of the process of generating an object, a texture is superimposed on that object's surface area. When preparing the photographs or graphics that are intended to serve as a texture, one should remember to select the appropriate resolutions and sizes. A photograph must provide an en-face image of an object so as to avoid distortions.

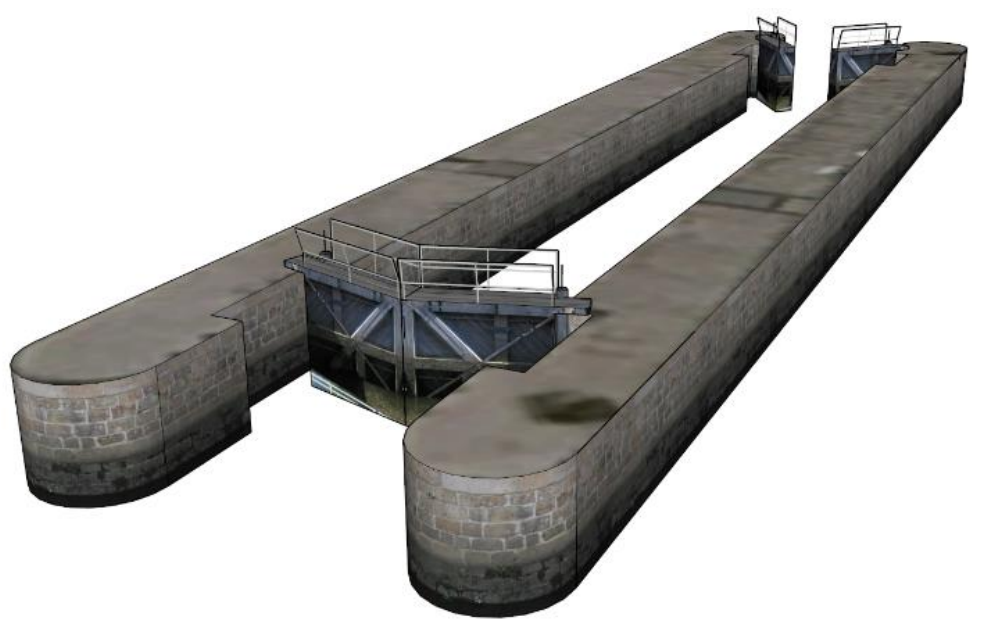

Fig. 9. Canal lock with superimposed textures 


\section{Importing the generated $3 D$ objects}

\section{and selecting objects from the program's database}

The next stage of creating a training body of water involves placing the last layer, which is constituted by $3 \mathrm{D}$ objects. New elements should be imported to the Model Wizard program and the existing ones are selected from the library of objects. A satellite image of the area can be used as a background in order to properly locate the real-life objects. A canal lock and bridges are the new structures which were generated for the purposes of the cut and positioned in accordance with the design.

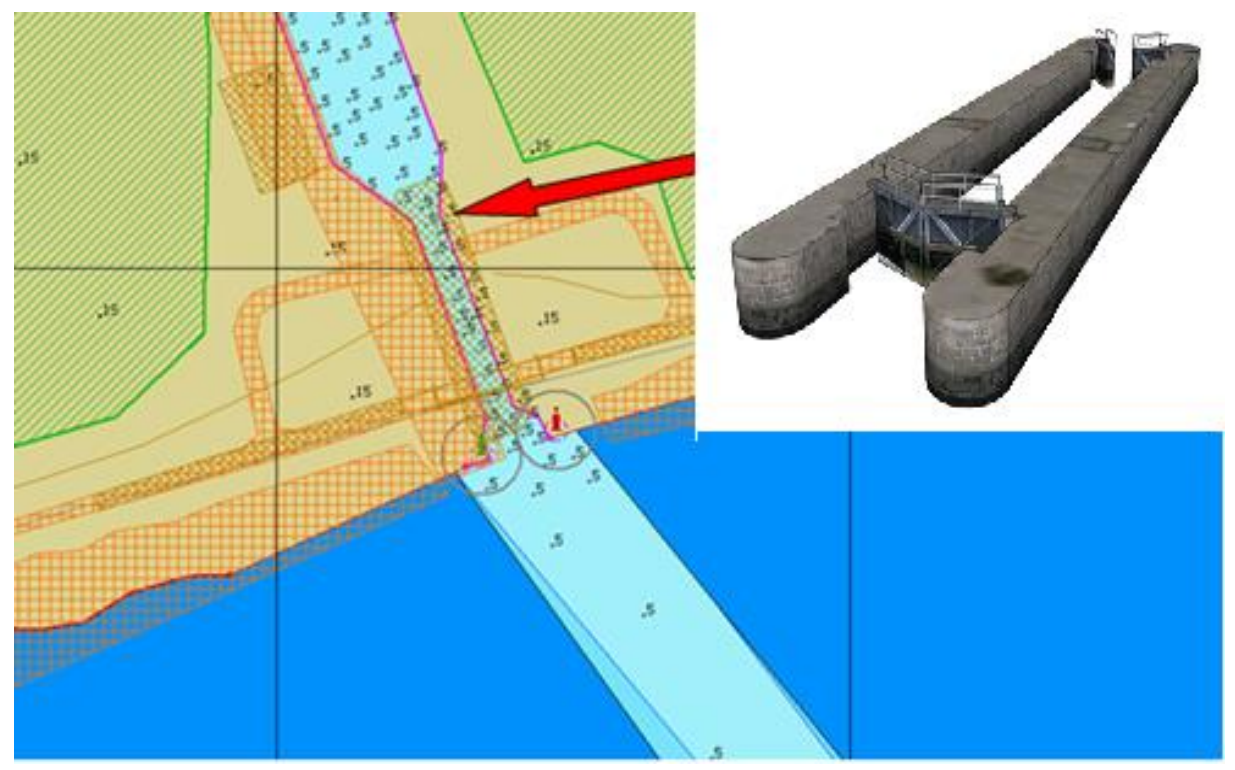

Fig. 10. Positioning internal and imported 3D objects in the design area

\section{Verifying the model's coherence by generating a 3D visualisation}

After completing the process of designing a body of water, one can verify its correctness. In order to do this, one should use the Visual Viewer function, which generates a 3D preview of the body water that has been created and makes it possible to preliminarily look at the designed landscape from any point, height and angle of view. This function allows one to generate the appropriate 
hydro-meteorological conditions and find out what influence they have on the area in question. It is also possible to see what the situation looks like at night in order to check whether the navigation lights function properly.

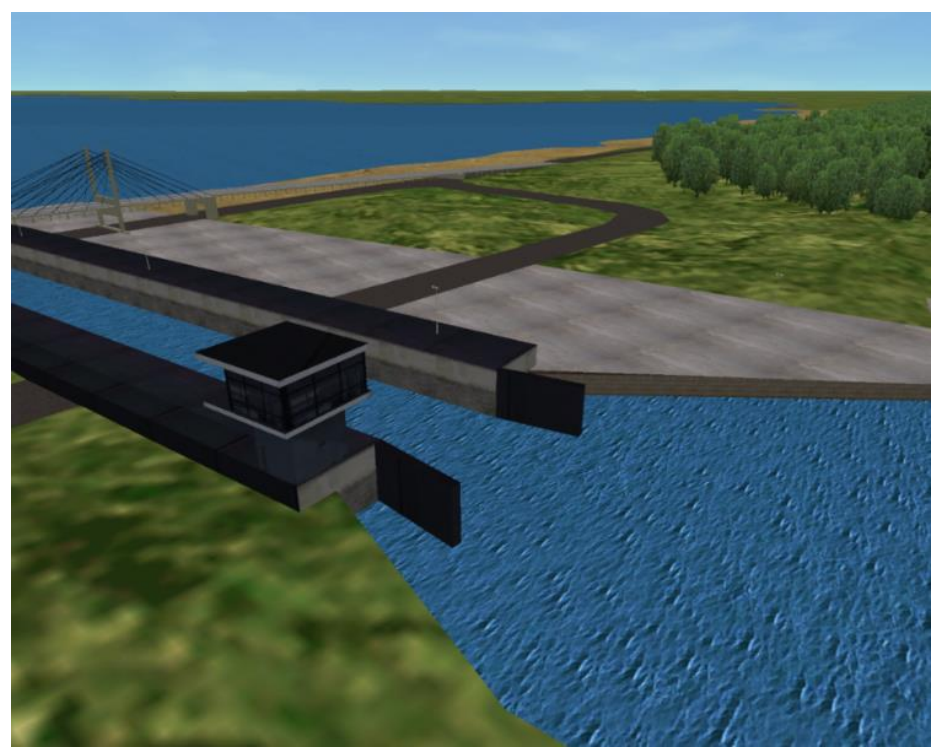

Fig. 11. Example image generated by the Visual Viewer

\section{SIMULATION TESTS}

In order to assess a body of water that is being designed in navigational terms, one should carry out a range of simulation tests under changeable hydro-meteorological conditions. These tests were conducted for all of the proposed design variants. Simulations of a vessel going through the canal were carried out for winds coming from the four main directions: the north, south, west and east. The wind's speed corresponded to forces 4 and 6 on the Beaufort scale. After the simulation, points at which the risk of collision was the highest were determined and then the influence of a given wind force on the likelihood of a collision was described. Also, the threshold value of wind force was determined, at which it would be impossible to safely manoeuvre a vessel. Additionally, tests were conducted concerning a vessel passing through the lock after being unmoored. The analysed variants only differed in terms of the location of the entrance to the cut, 
and apart from that, the structure of the canal was identical for all the alternatives. Therefore, there was no need to simulate a vessel's passage through the canal lock for each variant separately.

The model of a vessel that is used for research purposes is equipped both with two propellers and a bow thruster. Using two propellers and a thruster makes it possible to significantly reduce the turning circle diameter and even the turning diameter for a vessel that turns on the spot. However, it should be assumed that not all vessels are equipped in this way, which is why neither a thruster nor torques were used during tests. The tests were conducted by navy officers with different levels of professional experience.

The figure below presents partial results for one instance of a vessel's passage for the design variant that is shown in Figure 12. This structure allows a vessel to enter the cut from the east.

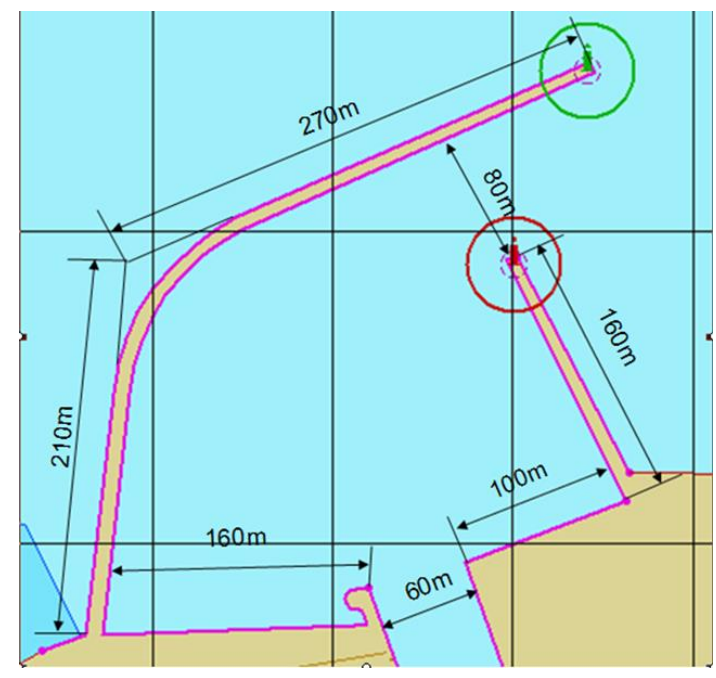

Fig. 12. Second design variant

Analysis of the rudder angle shows that the rudder must be in hard to port position when a vessel is executing a turning manoeuvre, even under perfect meteorological conditions. A significant decrease in a vessel's speed during a turning manoeuvre is another important parameter, which can limit that vessel's manoeuvring capabilities if it has reached its minimum manoeuvring speed. When analysing a vessel's track while it is moving under neutral conditions, one can notice that when passing the heads, a vessel goes much closer to the port head of the entrance. 
This is because it is forced to begin a turning manoeuvre, which ends right before the entrance to the canal, faster. In order to set a vessel on a course to enter the lock, one must manoeuvre in the canal, which proves that there may be a significant risk of collision in adverse meteorological conditions.

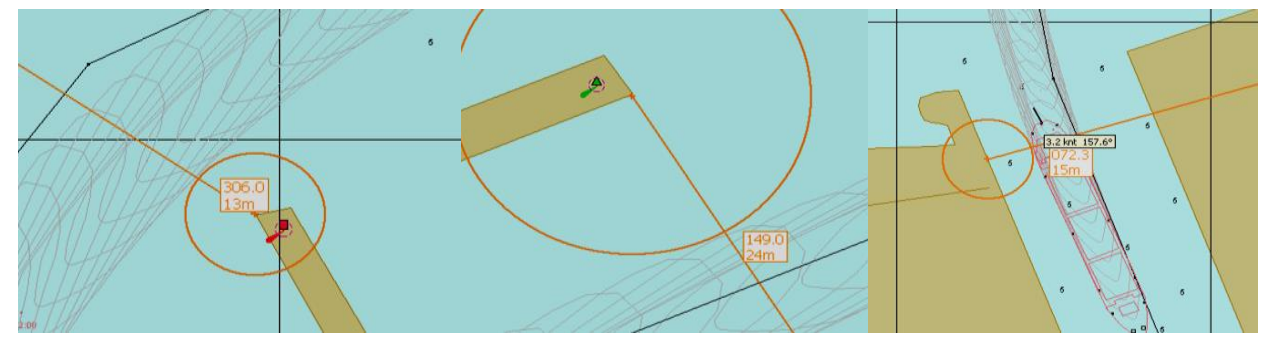

Fig. 13. Vessel's wake during a test conducted under neutral conditions

The results of the simulation tests allow one to draw conclusions which make it possible to select the best variant from among those that are analysed as regards navigational safety. The table below provides a simplified presentation of the test results for both variant entrances.

Table 1. Results of the tests for the first variant

\begin{tabular}{|c|c|c|c|c|}
\cline { 2 - 5 } \multicolumn{1}{c|}{} & \multicolumn{4}{c|}{ First variant } \\
\hline Wind & North & South & East & West \\
\hline $4^{\circ} \mathrm{B}$ & Successful & Successful & Successful & Successful \\
\hline $6^{\circ} \mathrm{B}$ & Successful & Successful & Successful & Failed \\
\hline
\end{tabular}

Table 2. Results of the tests for the second variant

\begin{tabular}{|c|c|c|c|c|}
\cline { 2 - 5 } \multicolumn{1}{c|}{} & \multicolumn{4}{c|}{ Second variant } \\
\hline Wind & North & South & East & West \\
\hline $4^{\circ} \mathrm{B}$ & Successful & Successful & Successful & Successful \\
\hline $6^{\circ} \mathrm{B}$ & Failed & Successful & Failed & Failed \\
\hline
\end{tabular}

Analysis of the tables that summarise the results of particular simulations shows that the first design variant failed one manoeuvring test, whereas the second design variant failed as many as three tests. This demonstrates that the first arrangement of wharves makes it possible to enter the area of the cut under much more difficult weather conditions. However, the failed attempt to enter the cut with a west wind of force 6 on the Beaufort scale shows that this structure is not perfect and requires certain adjustments. The first variant has a considerable advantage over 
the second one in terms of the distance that a vessel must travel while executing a turning manoeuvre. The need to make a turn of 20 degrees more makes it much more difficult to perform a manoeuvre when considering wharves with dimensions similar to the given ones. This is especially visible when the wind is strong. Three of the four tests that were conducted for the first variant were passed, while only one manoeuvre was successful when the second variant was used.

\section{CONCLUSIONS}

The tests that were carried out for the purpose of this study were aimed at collecting data which would allow one to select the more advantageous design variant or which would be a part of the process of making this choice. Therefore, the conclusions that can be drawn from this study are directed solely towards assessing these variants with regard to the influence of the wind's force and direction on navigational safety.

After examining both variants, one can state that the aim of this study has been achieved as it is possible to identify the better design alternative without major problems by analysing the simulation tests. The design with an east side entrance proved to be better. However, this structure is not perfect, and one of the conclusions that have been drawn from the tests is that it is necessary to move the entrance to the canal to the right. This will eliminate the negative influence from an east wind, which pushes a vessel and thus increases the turning circle radius. It can also be stated that this change will eliminate the frequent error that results from beginning a turning manoeuvre too late. These tests showed that this error is one of the most often repeated errors that are made during manoeuvres when they are performed by a human being.

The results allow one to state that the simulator that is used by the Polish Naval Academy is a good tool which can aid in preparing and verifying marine traffic engineering designs. Since being economical is very important these days, simulators, which are relatively inexpensive to use, have an additional advantage over real-world experiments.

\section{REFERENCES}

[1] Model Wizard User Manual, Transas Marine, Sankt Petersburg, 2011.

[2] Navi-Trainer Pro 5000 Ship Mathematical Model, Transas Marine, Sankt Petersburg 2011. 
[3] Navi-Trainer Pro 5000 User Manul, Transas Marine, Sankt Petersburg 2011.

[4] The construction of the water route junctive the Vistula's Bay with the Gdańsk Gulf [in Polish], The Gdynia Maritime Office, Gdynia 2015.

Received August 2015

Reviewed December 2015

PIOTR ZWOLAN

Polish Naval Academy

p.zwolan@amw.gdynia.pl

\section{KRZYSZTOF CZAPLEWSKI}

Gdynia Maritime University

krzysztof@czaplewski.pl

\section{STRESZCZENIE}

Największym problemem w procesie realizacji projektu budowy nowych akwenów morskich lub elementów systemów oznakowania nawigacyjnego jest sprawdzenie poprawności przyjętych założeń bez obniżania poziomu bezpieczeństwa na realnych akwenach. Współcześnie dostępne są cyfrowe modele pozwalające na łatwe i tanie zastępowanie dotychczas stosowanych metod badawczych. W tym zakresie idealnie sprawdzają się symulatory nawigacyjno-manewrowe.

Symulatory jako narzędzia badawcze pozwalają określać bardziej realistyczne i dokładne dane do badania i oceny dróg oraz akwenów wodnych. Celem symulacji jest identyfikacja i zmniejszenie ryzyka działalności marynarzy w specyficznych warunkach dróg wodnych, kanałów i akwenów portowych. Obejmuje ona ocenę ilościową i jakościową ukształtowania kanałów i torów wodnych. Głównym wymaganiem w odniesieniu do systemu symulacji jest posiadanie wielopoziomowego oprogramowania symulacyjnego, które obejmuje efektywne narzędzia repozycjonowania i projektowania bezpiecznych dróg wodnych i elementów infrastruktury portowej.

W Instytucie Nawigacji i Hydrografii Morskiej Akademii Marynarki Wojennej od lat osiemdziesiątych XX wieku realizuje się projekty z zakresu nawigacyjno-hydrograficznego zabezpieczenia działalności ludzkiej na morzu (NHZ). Jest to możliwe dzięki posiadaniu bogatego zestawu narzędzi symulacyjnych. Planowanie NHZ w wirtualnym środowisku symulatorów pozwoliło nie tylko na zaprojektowanie wirtualnych odpowiedników realnych fragmentów polskich obszarów morskich, ale również na ocenę jakości wytworzonych elementów NHZ przed ich rzeczywistym wystawieniem na akwenach morskich.

W artykule zaprezentowano możliwości symulatorów na przykładzie planowanego kanału żeglownego przez Mierzeję Wiślaną. Przedstawiono algorytm postępowania podczas tworzenia akwenu i próby manewrowe dla maksymalnej jednostki przewidzianej dla nowo powstałego akwenu. 